\title{
The Effects of Learning Disabilities of a Dyslexic toward Social Relationship in the Movie Like Stars on Earth
}

\author{
Indira Karina Putri \\ Balikpapan University \\ indiraaarin@gmail.com \\ Siti Hafsah \\ Balikpapan University \\ siti.hafsah@gmail.com \\ Jepri \\ Balikpapan University \\ jeprinainggolan@gmail.com
}

\begin{abstract}
:
Hermeneutics in this study is a theory that gives an interpretation of meanings and symbols which are interpreted as manifestations of a child's social relations with dyslexia. Humans through their minds like the ability to have a normal social life like in general with cultural norms and understandings that he considers correct by using interpretation as a tool for various purposes; one of the goals is to communicate with others as a form of adaptation to the environment. The study has significant value and can be motivated by the daily lives of children with dyslexia which are considered intelligence and normal people in general. The method in this study uses a qualitative descriptive research method with hermeneutics by Paul Ricoeur's theory, with two perspectives namely interpretations and symbols. From this research, researcher found several symbols that must be interpreted so that the meaning contained in them can be understood, where this movie provides motivation for parents or children with dyslexia.
\end{abstract}

Keywords: dyslexia, social relationship, hermeneutics, Like Stars on Earth

\section{INTRODUCTION}

Literary works are world constructed by the words, because words have power to construct everything even the world itself. The image that find in every side of the world can be 
depicted or portrayed through the words. Ratna (2005, p.150) stated that literary work can construct the world throughout words for the motive that words have power. By the side of statement, it is represented that through that power, it can form an image of particular world, as a new world. Those words have documentary aspects, it can break through space and times, illustrate past as well as future.

Literary work is a form of conveying messages by being packaged in the form of a work that can be accepted and enjoyed by the audience. There are several genres of literary works. The two main categories separating the different genres of literary work are fiction and nonfiction. It focuses to fiction literary work. The genre of fiction can be defined as narrative literary works whose content is produced by the imagination and is not necessarily based on fact. In fiction something is feigned, invented, or imagined; a made-up story. Those of fiction genre are poetry, fantasy, humor, fable, fairy-tales, science fiction, short story, realistic fiction, folklore, historical fiction, horror, a tall tale, legend, mystery, mythology, fiction in verse and drama.

The movie which is being an object of the research here is Like Stars on Earth, which tells a story about a dyslexic child who has learning disabilities because he is schooled in normal school and nobody knows about him being a dyslexic, including his parents and his brother. The disabilities for dyslexic are learning language, including word recognition, reading fluency, spelling, and writing. These are often not noticed until children enter school, where knowledge of written language is a major requirement.

Dyslexia is a disorder of the development of brain function that occurs throughout the life span. Generally, children who experience dyslexia, especially mild ones are considered as children who are stupid, lazy, lacking in effort, careless, resulting in inferiority, lack of confidence and experiencing secondary emotional disturbances. Though not infrequently people with dyslexia have high intension such as Nelson Rockefeller, Albert Einstein, Churchill called gifted dyslexics.

Learning disabilities of dyslexia usually become apparent when a child starts school and begins to focus more on learning how to read and write. A child with dyslexia may read and write very slowly, confuse the order of letters in words, put letters the wrong way round (such as writing "b" instead of "d"), have poor or inconsistent spelling, understand information when told verbally, but have difficulty with information that's written down, find it hard to carry out a sequence of directions and struggle with planning and organizing. People with dyslexia often have good skills in other areas, such as creative thinking and problem solving. Here, the example the learning disabilities of the dyslexic.

\section{LITERATURE REVIEW}

\section{Hermeneutics}

Hermeneutics in literature is a method for understanding the text described and intended for the study of literary texts. Hermeneutics is suitable for reading literary works because in literary studies, whatever they are, they are related to an activity namely interpretation. 
Literary appreciation activities and literary criticism, at the beginning and end, relate to literary works that must be interpreted. All activities of literary study - especially in the process - certainly involve the role of hermeneutical concepts.

Paul Ricoeur De l'interpretation (1965) in Sumaryono (1999: p.105), stated that Hermeneutics is a theory of the rules of interpretation, namely the interpretation of certain texts, or signs, or symbols, which are considered as texts". The main task of hermeneutics is on the one hand looking for internal dynamics that govern the structural work in a text. On the other hand, it seeks the power possessed by the work of the text to project itself out and allow 'the thing' to surface.

Hermeneutics can be understood as a kind of transitional something that is relatively abstract and dark, namely thoughts into clear expressions, namely in the form of language. Hermeneutics is an act of interpreting something, passing a less clear expression of thoughts leading to a clearer understanding, a form of thought that is less clear is transformed into a clearer form.

\section{Dyslexia}

Dyslexia comes from Greek, which is from the word "dys" which means difficulty, and the word "lexis" which means language. So dyslexia literally means difficulty in language. Dyslexic children not only have difficulty reading, but also in terms of spelling, writing and some other aspects of language. Difficulty reading in dyslexic children is not comparable with the level of intelligence or motivation possessed for the ability to read fluently and accurately, because dyslexic children usually have normal intelligence labels even some of them is above normal. Dyslexia is a disorder with a basic neurobiological disorder, which is characterized by difficulty in recognizing words correctly or accurately, in spelling and in the ability to code symbols.

Dyslexia is also defined as a condition of different input or information processing (from normal children) which is often characterized by difficulties in reading, which can affect cognitive ways such as memory, input processing speed, timing ability, coordination aspects and movement control. Jovita Maria Ferliana, in Living with Dyslexia (2007) stated; dyslexics actually have difficulty distinguishing the phonetic sounds that make up a word. They can capture these words with the senses of their listeners, but when they have to write them they have difficulty writing what they want into long, accurate sentences.

Dyslexia is a learning disorder that involves difficulty reading due to problems identifying speech sounds and learning how they relate to letters and words (decoding). Also called reading disability, dyslexia affects areas of the brain that process language. Specific learning disabilities caused by dyslexia originate from neurology. This situation is exacerbated by difficulties with accurate word recognition and poor spelling and wordbreaking abilities. These difficulties result from ineffective cognitive abilities.

\section{Social Barriers}

Social barriers are barriers caused by differences in social classes in society, including differences in education levels, age differences, differences in wealth or economic level, 
differences in social status, religion, and others. Social barriers in daily life affect someone in their social relations with society. According to Chris Smith (2019), there are several social barriers that can affect one's social life, namely the Perceptual Barrier, Emotional Barrier, Cultural Barrier, Interpersonal Barrier, Gender Barrier and Language Barrier. Based on the previous explanation, learning disabilities caused the social barriers that faced by the main character are affect to his social relationship.

\section{RESEARCH METHODOLOGY}

The type of this research used qualitative descriptive. Descriptive research is research that seeks to describe a phenomenon, event, event that occurs now. Descriptive research focuses on actual problems as they were at the time the research took place. Through descriptive research, researchers try to describe events and events that are the center of attention without giving special treatment to the event. The variables studied can be single (one variable) can also be more and one variable.

Djam'an Satori (2011: p.23) revealed that qualitative research conducted by researchers wanting to explore phenomena that cannot be quantified that are descriptive such as work step processes, formulas about recipes, definitions of what is meant by differences, differences between goods and services, pictures, styles, cultural procedures, physical models of artifacts and so on.

Qualitative research as a research method based on the philosophy of post positivism, is used to examine the conditions of natural objects, where researcher finding key instruments, data collection techniques with triangulation, data analysis is inductive or qualitative, and the results of qualitative research emphasize meaning rather than generalization.

\section{FINDINGS}

This section found the results of the study regarding the effects of learning disability of a dyslexic toward social relationship in the movie Like Stars on Earth. The discussion section is to follow with the detailed the description of the results obtained. The findings uses a table to represent the data obtained.

\section{Learning Disabilities of People with Dyslexia}

This section displays about the learning disabilities that suffered by Ishaan as the main character in Like Stars on Earth.

Table: 1 Learning Disabilities affect Social Relationship

\begin{tabular}{lcc}
\hline Learning Disabilities & Percentage & Excerpts \\
\hline Disabilities in Understanding & 63 & 12 \\
Directions & 16 & 3 \\
Reading Disabilities & 21 & 4 \\
Writing Disabilities & & \\
\hline
\end{tabular}




\section{Learning Disabilities affecting Social Relationship}

This section is about the learning disabilities affect the main character's social relationship in Like Stars on Earth. There are some barriers caused by learning disabilities that affect to main character's social relationship. The barriers that consist in the learning disabilities are perceptual barriers, emotional barriers, cultural barriers and language barriers. However, gender barriers and physical barriers were not find in search of barriers which affect the main character's social relationship.

\section{DISCUSSION}

Learning disabilities are problems that affect how people receive and process information. People with learning disabilities have trouble in learning especially in academic and it affect to their social relationship.

This study focuses on the learning disabilities of the main character in the movie Like Stars on Earth. Based on the explanation about learning disabilities, the researcher classified the learning disabilities into 3 categories there are reading, writing and understanding directions. By using hermeneutic theory by Paul Ricoeur, the researcher comprehends the conversations in the movie and interprets the dialogue also the symbol which appears in the movie.

\section{Learning Disabilities}

There are three disabilities in this research, those are disabilities of understanding direction, disabilities of writing and disabilities of reading. Each disability affects to the social relationship and become barriers in the social life. Those barriers are (a) Interpersonal Barriers; the most frequent barriers data appearance is interpersonal barriers. The frequent appearing of the data shows that for people who do not know about dyslexic would face interpersonal barriers. It means that people who had relationship with dyslexic would get misunderstanding, (b) Perceptual Barriers; The perceptual barriers come second as the most frequent data. The frequent appearing of the data shows that for people who do not know about dyslexic would face perceptual barriers. It means that people assume the dyslexic as a bad, fool or lazy. But indeed, dyslexic is not like the assumption, (c) Cultural Barriers; the cultural barriers come third as the frequent data. In this life, people live with culture that normal people is a good people. In fact, some people had some disabilities and difficulties so in general, need to know other people with special necessary, (d) Emotional Barriers; the emotional barriers come as the less data. In this life, people with disability will assumed as an abnormal people and sometimes made mistakes. But for normal people, it would build some emotional and gap the social relationship.

\section{Learning Disabilities affect Social Relationship}

Learning disabilities could affect one's social relationship. For normal people, social relationship would be normal. People with learning disabilities affect to their social relationship. The learning disabilities make the barriers between people to their social life such as in this movie, the main character got some barriers caused by his dyslexia. This 
movie is, therefore, a good example in showing how learning disabilities can affect social relationship especially in the context of the life of people with dyslexia.

\section{CONCLUSION}

The learning disabilities are found through this research are as follows. First, the disabilities of understanding directions is found. This is the most frequent data appeared in the research. It shows that a dyslexic person is unable to understand command and rule, more the dyslexic could not follow the multiple instructions and it is so hard to remember the daily activities. Second, the disabilities in writing is found. For a dyslexic person or child, he/she faces some difficulty to write. Third, disabilities in reading is found. Disabilities in reading is faced by the main character in some scenes, but it is not frequently shown.

The learning disabilities found in the movie affect the social relationship. The social barriers that faced by the main character as impact of the learning disabilities are as follows: (a) Interpersonal Barriers; the most frequent barriers data appearance is interpersonal barriers. The frequent appearing of the data shows that for people who do not know about dyslexic would face interpersonal barriers. It means that people who had relationship with dyslexic would get misunderstanding. (b) Perceptual Barriers; The perceptual barriers come second as the most frequent data. The frequent appearing of the data shows that for people who do not know about dyslexic would face perceptual barriers. It means that people assume the dyslexic as a bad, fool or lazy. Indeed, dyslexic is not like the general assumption. (c) Cultural Barriers; the cultural barriers come third as the frequent data. In this life, people live with culture that normal people is a good people. In fact, some people had some disabilities and difficulties so in general, need to know other people with special necessary. (d) Emotional Barriers; the emotional barriers come as the least in the data. In this life, people with disability will assumed as an abnormal people and sometimes made mistakes. For normal people, it would build some emotional and gap the social relationship. The reader on the topics identified how the learning disabilities that suffered by a dyslexic child could affect to his social relationship of the main character in the movie Like Stars on Earth.

\section{References}

Abdul, H. W. M. (2004). Hermeneutika, estetika, dan religiusitas: Esai-esai sastra sufistik dan seni rupa. Depok, Sleman, Yogyakarta: Mahatari.

Berrett, S. (2010). Reading Horizons Student Workbook. North Salt Lake, UT: Reading Horizons.

Bezsylko, S. (2015). How Can We Help Kids With Non-Verbal Learning Disorder? Retrieved May 12, 2019, from https://www.winstonprep.edu/blog/science-oflearning/how-can-we-help-kids-with-non-verbal-learning-disorder/ 
Bleicher, J. (2003). CONTEMPORARY HERMENEUTICS: Hermeneutics as method, philosophy and critique. Retrieved May 25, 2019, from https://books.google.co.id/books?isbn=1351622374

Faiz, F. (2002). Hermeneutika qurani: Antara teks, konteks, dan kontekstualisasi. Yogyakarta: Penerbit Qalam. Retrieved May 25, 2019, from http://docplayer.info/49786028-Hermeneutika-sebagai-sistem-interpretasi-paulricoeur-dalam-memahami-teks-teks-seni.html

Frith, U. (2015). Autism explaining the enigma. Malden, MA: Blackwell Publishing. Retrieved May 10, 2019, from https://dyslexiaida.org/wpcontent/uploads/2015/01/DITC-Handbook.pdf.

Kagan, G. L. (2018). Social Barriers. Retrieved June 24, 2019, from https://www.disabilityinclusionguild.org/social-barriers/

Klarer, M. (2013). An introduction to literary studies. London: Routledge. Retrieved May 11, 2019, from https://faculty.psau.edu.sa/.../doc-11-pdf788778a8f953a97e417c44350713c77e-orig.

Krueger, P. (2010). An explanation of Dyslexia. Retrieved May 02, 2019, from https://bismarcktribune.com/lifestyles/health-med-fit/an-explanation-ofdyslexia/article_d05652e0-e03e-11df-afa0-001cc4c002e 0.html

Moleong, L. J. (2009). Metodologi penelitian kualitatif. Retrieved May 10, 2019, from library.um.ac.id/free.../metodologi-penelitian-kualitatif-lexy-j-moleong-38045.html.

Martinelli, K. (2015). Understanding Dyslexia. Retrieved May 11, 2019, from https://childmind.org/article/understanding-dyslexia/

Palmer, R. E. (2003). Hermeneutics; interpretation theory in Schleiermacher, Dilthey, Heidegger, and Gadamer I. Evanston: Northwestern University Press. Retrieved May 25, 2019, from http://docplayer.info/47861701-Modul-ke-teori-komunikasi-teoriinterpretif-fakultas.html

Ratna, N. K. (2005). Sastra dan cultural studies: Representasi fiksi dan fakta.

Reid, G. (2009). The Routledge companion to dyslexia. London: Routledge.

Ricoeur, P (2016). Hermeneutics and the human sciences: Essays on language, action, and interpretation. New York: Cambridge University Press.

Satori, D. (2010). Metodologi Penelitian Kualitatif. Bandung: Alfabeta.

Smith, C. (2019). Professor Christopher Smith: International Research: Benefits and Barriers. [online] Institute of Advanced Studies (IAS). Available at: https://www.ucl.ac.uk/institute-of-advanced-studies/events/2017/feb/professorchristopher-smith-international-research-benefits-and-barriers

Sonneborn, L. (2011). Mark Twain. New York: Chelsea House. Retrieved May 12, 2019.

Sugiyono. (2008). Metode penelitian pendidikan: (pendekatan kuantitatif, kualitatif dan $R$ $\& D)$. Bandung: Alfabeta.

Sukmadinata, N. S. (2005). Metode penelitian pendidikan. Bandung: Program Pascasarjana Universitas Pendidikan Indonesia dengan PT Remaja Rosdakarya.

Sumaryono, E. (1999). Hermeneutik, sebuah metode filsafat. Yogyakarta: Kanisius.

Teeuw, A. (1994). Sastra dan ilmu sastra: Pengantar teori sastra. 